\title{
FENOMENOLOGI : CARING PERAWAT TERHADAP KLIEN DENGAN KONDISI KRITIS DI INSTALASI GAWAT DARURAT - RUMAH SAKIT dr. SAIFUL ANWAR MALANG
}

(Phenomenology: caring of nurse for clients with critical conditions at emergency installation-dr. Saiful Anwar Hospital)

\author{
Janes Jainurakhma ${ }^{1}$, Indah Winarni ${ }^{2}$, Setyoadi ${ }^{3}$ \\ ${ }^{1}$ Program Studi Keperawatan Peminatan Gawat Darurat Fakultas Kedokteran Universitas \\ Brawijaya \\ ${ }^{2}$ Fakultas Ilmu Budaya Universitas Brawijaya \\ ${ }^{3}$ Program Studi Ilmu Keperawatan Fakultas Kedokteran Universitas Brawijaya \\ Email : janesjainurakhma@yahoo.com
}

\section{ABSTRACT}

Caring is an important part of nursing process that difficult to be apart. Emergency nursing is a profession that required health care providers with fast performance, accurate, and quality of complicated and holistic problems. A lot of patients with critical condition at emergency department, they ask a quality of nursing services and it is affected by the quality of a nurse caring. Without caring passion, a nurse vulnerable to act that violate ethical of nursing, no exception nursing profession at emergency installations of RSSA Malang. The purpose of this study is to explore the experience of nurse caring for clients with critical condition at emergency installations of RSSA Malang. This study used a qualitative approach, with interpretive phenomenological method. Purposive sampling is a method used in this study, the criteria of experience as nurse in the emergency installations of RSSA Malang at least 5 years, still working in the emergency installations of RSSA Malang, and willing as participant. Using semi-structure interviews technique, and analyzed by Miles and Huberman model approach. The results led to three themes, namely: the resque of critically ill patients, improve patient and family confidence, desire to do the best for crical patients. Based on the results of the study are expected to follow up with the theme of the next study of emergency nurses caring of the perpective of patient and families, and needs to be improved further for the training of emergency skill of nurses in the emergency department, so thet skills and knowledge of nurses in handling critical patients better.

Key words: caring, nursing experience, critical patient. 


\section{LATAR BELAKANG}

Profesi keperawatan merupakan suatu profesi yang mengedepankan pelayanan asuhan keperawatan yang holistic, dimana kualitas dari pemenuhan kebutuhan secara biologi - psikologi sosiologi - budaya dan spiritual klien beserta keluarga menjadi prioritas utama dalam setiap pelayanannya (Vanlaere \& Gastmans, 2011; Lachman, 2012; Bailey, 2011; Tonges \& Ray, 2011; Halligan, 2006).

Pelayanan keperawatan menuntut perawat menjadi sosok yang professional, dimana skill(ketrampilan), knowledge(pengetahuan), sensitif, empati, semangat ingin menolong, rasa tanggung jawab, dorongan moral (akhlak) dan attitude (sikap) dari seorang perawat terhadap diri dan lingkungannya harus tetap terjaga harmonis dengan mengedepankan nilai-nilai etik keperawatan secara berkesinambungan dalam setiap pelayanan yang diberikan (Lachman, 2012; Rundqvist, Kerstin, Delmar, 2011; Watson Caring Science Institute, 2010, Watson, 2009).

Nilai-nilai yang diterapkan dalam etik keperawatan menuntut perawat menjadi seseorang yang mampu mengembangkan diri dan bekerjasama dengan tenaga kesehatan lainnya, dimana tetap memegang nilai-nilai caringseperti berbuat baik, tidak melukai, keadilan, kejujuran, yang bertujuan untuk kebaikan dari klien sebagai manusia secara utuh, unik, dan bermartabat, sehingga tercipta kualitas caring yang terbaik (high quality of caring) (Canadian Nurses Association, 2001; Notoatmodjo, 2010; Persatuan Perawat Nasional Indonesia, 2012; Lachman, 2012).

Widyarini (2005) memaparkan hasil studinya, berdasarkan wawancara terhadap pasien, menyatakan bahwa perawat memiliki nilai etik profesi (humancaring dan relasi sosial) adalah perawat yang tidak melakukan malpraktek (seperti menaikkan jumlah pemakaian alat yang seharusnya tidak dibeli oleh pasien), memberikan informasi yang dibutuhkan oleh pasien, tidak membeda-bedakan, bekerja secara tim, ramah sesuai dengan budaya. Hasil studi diatas menunjukkan bahwa perawat memiliki fungsi yang penting sekali dimata seorang pasien, sehingga tanpa adanya jiwa caring yang baik dari seorang perawat saat mereka bertugas, hal tersebut rentan sekali menimbulkan pelanggaran terhadap nilai etik profesi keperawatan.

Caring yang muncul dalam performa seorang perawat bersumber pada beberapa faktor, diantaranya : kepeduliaan terhadap seseorang yang menderita, adanya rasa ingin menolong secara alami, rasa cinta terhadap sesama, adanya rasa 
kemanusiaan yang mendalam, adanya keinginan untuk berkorban, rasa tanggungjawab, panggilan Tuhan, keinginan menolong karena nilai-nilai moral yang dianut (Rundqvist, Kerstin, Delmar, 2011).

Caring seorang perawat tetap mempertahankan serta mampu meningkatkan harga diri seorang klien dengan memperhatikan segala kelebihan dan kekurangan dari klien, selain itu respon dari seorang klien dengan berbagai macam penderitaan yang sedang dialami oleh klien (Watson, 2010, 2009, 2008; Lachman, 2012). Pendekatan proses caringyang diungkapkan oleh Watson dalam "human caring science" dengan sepuluhcarative factors, merupakan suatu tuntutan profesi keperawatan yang ditunjukkan dalam proses keperawatan yang berkualitas, hal tersebut yang dijadikan tuntutan dalam asuhan keperawatan di instalasi gawat darurat (IGD), tidak terkecuali profesi keperawatan di IGD rumah sakit dr. Saiful Anwar (RSSA) Malang.

Tanpa caring membuat seorang perawat dalam memberikan pelayanan keperawatan rentan terhadap tindakan yang melanggar etik keperawatan, terlebih lagi kondisi klien saat menghadapi kondisinya yang kritis di instalasi gawat darurat ada yang dalam tingkat sadar penuh bahkan seringkali dalam kondisi penurunan kesadaran.

Pentingnya caring dalam suatu kualitas proses keperawatan di area gawat darurat, membuat ketertarikan peneliti untuk mengeksplorasi pengalaman caring perawat terhadap klien dengan kondisi kritis di instalasi gawat darurat rumah sakit dr. Saiful Anwar Malang. Diharapkan hasil penelitian semakin membuka wacana dan menambah pengetahuan perawat maupun pendidikan khususnya dalam dunia keperawatan tentang fenomena yang terjadi dalam dunia keperawatan kegawatdaruratan, ketika menghadapi klien dengan kondisi kritis, dan berguna dan memberikan masukan yang bersifat positif bagi profesi keperawatan, baik dalam penentuan berbagai macam kebijakan pelayanan asuhan keperawatan di departemen kegawatdaruratan maupun bagi manajerial sebuah pelayanan kesehatan dalam peningkatan kualitas pelayanan khususnya keperawatan di departemen kegawatdaruratan.

\section{METODE PENELITIAN}

Penelitian ini menggunakan pendekatan kualitatif, dengan metode fenomenologi interpretive. Penelitian kualitatif bertujuan untuk mengembangkan dan memperkaya pemahaman akan sebuah fenomena yang 
terjadi di sekeliling kita (berasal dari lapangan) dan menjadikan sebuah gagasan dalam sebuah hubungan fenomena (kejadian tertentu) (Chase, 2005; Winarni, 2012)

Purposive sampling merupakan cara yang akan dipakai dalam penelitian ini, sehingga diharapkan akan memperoleh gambaran utuh tentang suatu kasus, dimana dalam penelitian ini akan meneliti tentang caring perawat saat menghadapi klien dengan kondisi kritis di instalasi gawat darurat. Penentuan partisipan (nara sumber) dilakukan secara purposive dengan kriteria tertentu (Loiselle, Profetto-McGrath, Polit dan Beck, 2011): pengalaman sebagai perawat di IGD minimal 5 tahun, masih bekerja di IGD saat itu juga, dan bersedia sebagai partisipan. Wawancara semiterstruktur (semistructure interview) dilakukan dalam pengumpulan data penelitian ini dengan harapan peneliti mengumpulkan jenis data yang sama dari tiap partisipan dan peneliti dapat mengembangkan pertanyaan sesuai dengan topik yang akan digali (Rachmawati, 2013; Sugiyono, 2011; Loiselle, Profetto-McGrath, Polit dan Beck, 2011), dengan harapan akan didapatkan issu (data) lebih terbuka dan adanya rapport (rasa percaya dan hubungan emosional).

Lama waktu wawancara dilakukan selama satu jam, dengan melakukan kontrak terlebih dahulu kepada partisipan, tepat seperti yang diinginkan dan partisipan tidak sedang bertugas, sehingga partisipan akan merasa aman, nyaman dan santai (rileks) saat memberikan informasi, wawancara akan dilakukan melalui beberapa kali pertemuan jika diperlukan untuk mendapatkan hasil yang akurat.

Analisis data kualitatif bersifat induktif, sehingga data "caring perawat IGD saat menghadapi klien dengan kondisi kritis di IGD RSSA Malang” yang didapatkan dari lapangan (hasil wawancara, hasil observasi, catatan lapangan, dan bahan-bahan yang lain) selanjutnya dikembangkan menjadi sebuah hipotesis.

Model analisis data yang akan digunakan dengan pendekatan Miles dan Huberman, dimana analisis data kualitatif dilakukan secara interaktif dan berlangsung secara terus menerus sampai tuntas, sehingga datanya sudah jenuh, dengan aktifitas data reduction (reduksi data), data display (penyajian data), dan conclusion drawing/verification (Sugiyono,2011).

\section{HASIL PENELITIAN}

Penelitian ini menghasilkan tiga tema, berdasarkan hasil wawancara seputar nilai-nilai caring yang muncul dari pengalaman partisipan saat merawat klien dengan kondisi yang kritis di IGD RSSA 
Malang. Beberapa tema yang dihasilkan berdasarkan hasil analisis transkrip wawancara, yaitu : melakukan penyelamatan pasien kritis, meningkatkan kepercayaan pasien dan keluarga, keinginan berbuat yang terbaik untuk pasien kritis.

Melakukan penyelamatan pasien kritis dimaknai sebagai perilaku perawat dalam usaha membantu pasien dari kondisi yang mengancam jiwa, dimana perawat melakukan berbagai kegiatan kegawatdaruratan, seperti tindakan resusitasi, kerjasama antar petugas kesehatan, berinteraksi dengan keluarga pasien dalam meminta persetujuan tindakan, dimana dituntut untuk bertindak cepat dan tepat, yang kesemuanya bertujuan untuk keselamatan pasien kritis di IGD.

Mengupayakan penyelamatan pasien kritis membutuhkan tindakan segera, dan tepat, dimana tidak ada lagi waktu tunggu, hal ini dikhawatirkan adanya permasalahan yang mengancam kepatenan "ABC “ (airway-breathingcirculation) pasien, sehingga berdasarkan pengalaman perawat tersebut menuntut suatu tindakan segera atau tidak ada waktu tunggu, yang sering mereka sebut dengan respon time 0 (nol).

"Kalo pasiennya kritis mesti kategorinya P1, jadi saya harus mengerjakan tindakan yang cepat dan tepat..." (PP3)

"Respon timenya langsung, ABC nya sangat terganggu, jadi itu yang kita tangani dulu, tidak ada waktu tunggu. "(PP5)

Tindakan yang cepat dan segera dari perawat IGD dipengaruhi oleh rasa tanggap dan keaktifan dalam tim resusitasi yang telah tertuang dalam protap IGD, dimana paling sedikit ada empat orang penolong dengan pembagian tanggungjawab masing-masing penolong. Adanya pembagian tugas dalam tindakan resusitasi, maka mengupayakan penyelamatan pasien kritis lebih besar. 


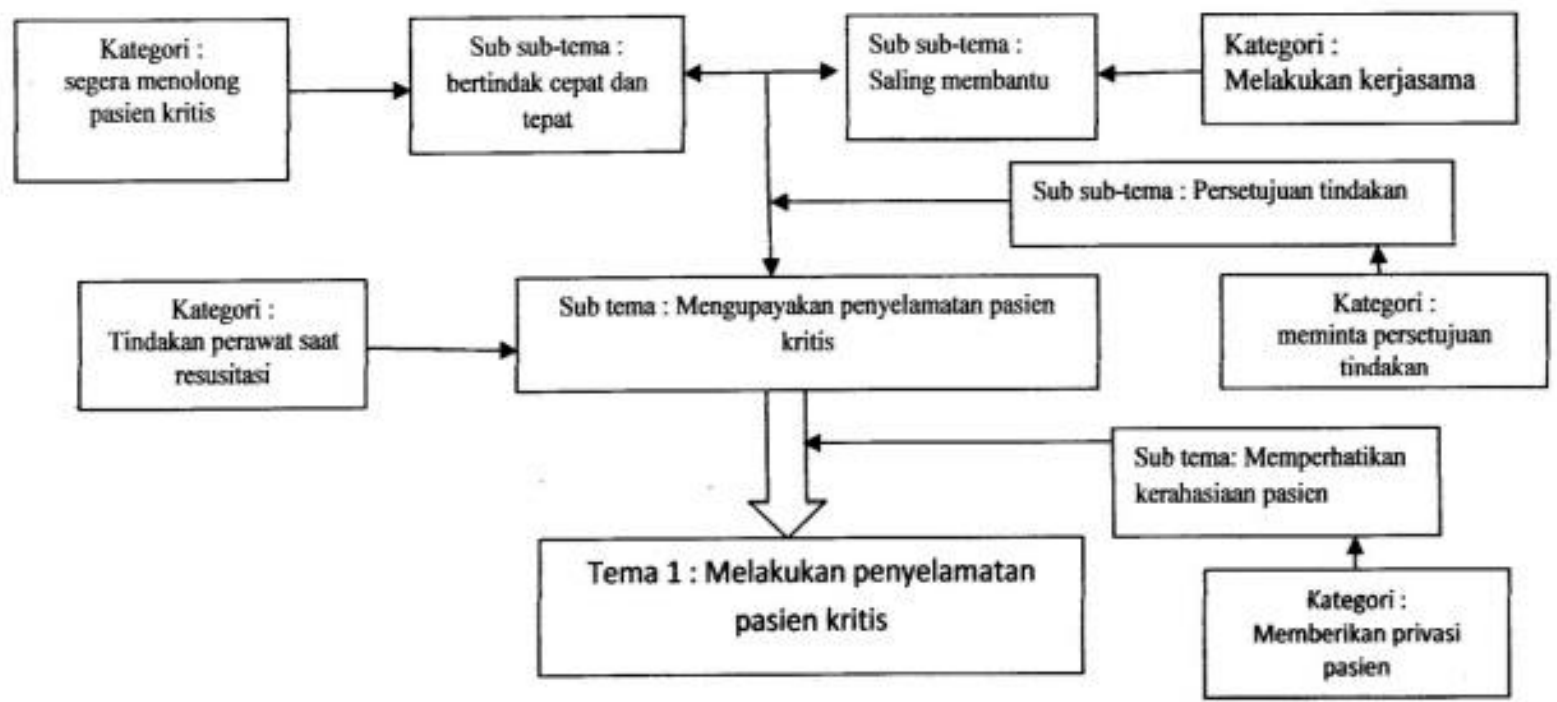

di IGD RSSA Malang selalu mengutamakan keselamatan pasien terlebih dahulu, baik pasien datang ke IGD tanpa ataupun disertai oleh keluarga, tidak mempengaruhi upaya penyelamatan pasien kritis tersebut, sehingga ada kalanya persetujuan tindakan kegawatdaruratan terhadap pasien kritis terhadap keluarga (jika pasien tidak sadarkan diri) dilakukan setelah pasien stabil, namun jika pasien sadar persetujuan tindakan akan tetap dilakukan terhadap pasien langsung.

Upaya penyelamatan pasien kritis di IGD RSSA Malang tidak hanya membutuhkan ketrampilan dan kemampuan intelektual saja, namun dalam penerapannya menurut pengalaman perawat membutuhkan suatu rasa kepercayaan pasien dan keluarga terhadap petugas IGD, karenangya perlu adanya dan keluarga dalam setiap proses tindakan kegawatdaruratan.

Meningkatkan kepercayaan pasien dan keluarga menurut pengalaman perawat IGD, dimaknai sebagai perilaku perawat dan petugas kesehatan dalam meningkatkan rasa nyaman pasien saat dirawat, menenangkan keluarga dengan memberikan penjelasan dan melibatkan keluarga saat pasien kritis, menghadirkan keluarga saat tindakan kegawatdaruratan serta menghormati keyakinan pasien dan keluarga dalam setiap tindakan.

Menenangkan pasien adalah harapan perawat saat merawat pasien dengan kondisi kritis, dimana dibutuhkan banyak ketrampilan komunikasi saat perawat berinteraksi dengan pasien kondisi kritis, dengan demikian pasien akan merasa nyaman, dengan demikian diharapkan pasien lebih tenang. 
"Ditanya sambil agak setengah hypno terapi begitu, ditanya, cuma dari main kata-kata begitu, misalnya ..."Pak gimana sudah enak?", nah itu pasiennya biasanya akan semakin lebih enak, ...”(PP1)

Keterlibatan keluarga juga dibutuhkan, dengan demikian akan menenangkan keluarga pasien yang cemas dan takut akan kondisi keluarganya yang mengalami kondisi kritis, sekaligus mampu meningkatkan kepercayaan keluarga dan pasien yang sedang dirawat.

"Kalo pasien kritis, kita jelaskan tentang tindakan, kondisi klien, tindakan yang sudah dilakukan dan yang akan dilakukan. Kalo tindakan yang akan kita lakukan mengandung unsur biaya, juga kita jelaskan, karena itu butuh persetujuan keluarga, perlu biaya, ...”(PP5)

Kehadiran keluarga saat melakukan tindakan kegawatdaruratan seperti proses resusitasi ataupun CPR (cardio pulmonary resuscitation) merupakan salah satu cara yang diperlukan untuk meyakinkan pihak keluarga terhadap tindakan dan tingkat kegawatan kondisi keluarga mereka. Beberapa kasus juga tidak perlu menghadirkan keluarga, hal ini ditakutkan akan mempengaruhi kondisi keluarga pasien tersebut, saat melihat tindakan yang menakutkan bagi diri keluarga, seperti pemasangan ETT (endo tracheal tube), dengan demikian keluarga pasien dipersilakan menunggu diluar selama tindakan resusitasi.

“...pada saat CPR, itu keluarga kita ijinkan masuk, jadi keluarga sudah melihat tindakan kita, melihat seberapa gawatnya anggota keluarga mereka, dan keluarga kita suruh membisikki doa di telinga, membantu kita dengan doa.'(PP5)

Perawat IGD banyak menemui fenomena saat bertugas, dimana keluarga atau pasien menggunakan benda-benda yang dianggap memiliki kekuatan menyembuhkan atau meminumkan minuman yang dianggap memiliki kekuatan menyembuhkan menurut kepercayaan mereka (keluarga dan pasien). Beberapa kejadian diatas membuat perawat memutuskan apa yang terbaik bagi pasien kritis, disatu sisi mereka memperbolehkan, disatu sisi tidak memperbolehkan melakukan atau mengenakan atau meminumkan hal-hal yang dianggap oleh perawat semakin membahayakan keselamatan pasien, dengan komunikasi yang baik terhadap keluarga tentunya.

"... maka tidak boleh diminumkan ...”bu ibu kalo pasiennya cedera kepala..pasiennya dipuasakan, airnya dibasahi saja dibibirnya, jangan diminumkan nanti membahayakan pasiennya, jadi ya tidak boleh diminumkan..." (PP1) “... biasanya itu ada yang bawa air zam-zam lalu di blonyohne ( dioleskan) ke tubuhnya, ada seperti itu.... selama dikasihkan diluar 
keluarga perawat sendiri bahkan membayangkan hal tersebut adalah diri perawat sendiri yang pada saatnya nanti juga akan mengalami kematian.

“...lebih banyak mengintrospeksi pada diri saya sendiri...mengingatkan saya, bahwa suatu saat saya juga akan mati..."(PP3)

Tugas sebagai perawat IGD yang mereka laksanakan bukan lagi sebagai beban yang berat, namun rasa senang yang muncul dalam diri partispan seiring dengan banyaknya pengalaman partisipan dalam merawat klien dengan kondisi kritis, menjadikan pengalaman tersendiri yang menyenangkan untuk dilakukan. Suasana lingkungan di IGD RSSA sangat mendukung perawat berkembang kearah perubahan yang positif dalam kehidupan mereka

\section{PEMBAHASAN}

Hasil penelitian menunjukkan adanya suatu pengalaman caring yang menyenangkan yang dirasakan oleh perawat IGD RSSA Malang dengan berbagai macam persepsi saat menghadapi klien dengan kondisi kritis di P1 (critical care area), di mana ditemukan 3 tema : melakukan penyelamatan pasien kritis, meningkatkan kepercayaan pasien dan keluarga, dan keinginan berbuat yang terbaik untuk psien kritis
Upaya penyelamatan pasien lewat tindakan resusitasi membutuhkan kerjasama tim yang solid. Pengalaman perawat saat bertugas di IGD selalu mengutamakan keselamatan pasien P1 (prioritas1), dimana perawat tidak hanya bertugas di area masing-masing, namun lebih fleksibel, maka saling membantu dalam mengisi kekosongan peran, dengan demikian berbagai macam usaha dalam menjaga kestabilan jalan nafas, pernafasan dan srkulasi pasien dapat dilakukan dengan cepat.

Peran perawat diatas dilakukan demi memenuhi kebutuhan dasar pasien kritis, mengatasi kecemasan pasien dan atau keluarga, menghargai privasi klien, memberikan berbagai macam pengobatan dan tindakan untuk kepatenan $\mathrm{ABC}$, resusitasi cairan, dan melakukan observasi secara berkala lewat monitor jantung yang telah terpasang ditubuh pasien.

Perilaku perawat tersebut sesuai dengan nilai-nilai caring, dimana carative factor kesembilan, perawat membantu dalam memenuhi kebutuhan dasar manusia dengan tetap menjaga martabat klien secara menyeluruh. Perawat mampu berperan aktif dalam memenuhi kebutuhan dasar yang dibutuhkan oleh klien, dengan berperan aktif dalam proses keperawatan pengkajian, penegakan diagnosa keperawatan, perencanaan suatu intervensi keperawatan, observasi dan 
evaluasi terhadap kondisi klien (Watson 2007; 2008; 2009; 2010; Chase, 2005; Okoye, 2012).

Meningkatkan kepercayaan pasien dan keluarga menurut pengalaman perawat IGD, dimaknai sebagai perilaku perawat dan petugas kesehatan dalam meningkatkan rasa nyaman pasien saat dirawat, menenangkan keluarga dengan memberikan penjelasan dan melibatkan keluarga saat pasien kritis, menghadirkan keluarga saat tindakan kegawatdaruratan serta menghormati keyakinan pasien dan keluarga dalam setiap tindakan.

Perilaku yang segera memenuhi kebutuhan pasien saat dirawat, merupakan hal-hal yang berdampak besar pada kepercayaan pasien terhadap perawat, sehingga hal tersebut mampu memberikan rasa tenang terhadap perawat.

Perilaku perawat IGD diatas sesuai dengan nilai-nilai carative factor keempat adalah membangun kepercayaan demi terciptanya caring relationship (hubungan caring) saat memberikan pertolongan. Caring yang ditunjukkan lewat pertolongan seorang perawat merupan hubungan interpersonal (manusia satu dengan manusia yang lain), dimana dalam menjalin hubungan yang baik maka harus terbentuk suatu hubungan saling percaya yang yang baik antara perawat dan klien. (Watson 2007; 2008; 2009; 2010; Chase, 2005; Okoye, 2012).
Tindakan kegawatdaruratan yang dilakukan perawat membutuhkan persetujuan dari kedua belah pihak, pihak pasien atau keluarga yang mewakili dan pihak IGD, karenanya penting sekali dalam setiap penanganan kegawatdaruratan pasien dengan kondisi kritis menginformasikan setiap tindakan dan kondisi pasien saat dirawat. Keterlibatan keluarga juga dibutuhkan, dengan demikian akan menenangkan keluarga pasien yang cemas dan takut akan kondisi keluarganya yang mengalami kondisi kritis, sekaligus mampu meningkatkan kepercayaan keluarga dan pasien yang sedang dirawat.

Perilaku perawat menurut Chase (2005) dan Okoye (2012) memberikan dampak yang besar terhadap hubungan edukasi (belajar-pembelajaran), pada tahapan proses caring ini, perawat memberikan bantuan tentang belajarmengajar sesuai dengan informasi apa yang dibutuhkan oleh pasien dan keluarga pada saat itu. Peran perawat dalam memfasilitasi kebutuhan klien akan berbagai sumber informasi akan mempengaruhi berbagai perkembangan klien dan keluarga pasien pada saat kondisi kritis, baik secara kognitif, emosi yang dirasakan oleh klien, persepsi, kesiapan klien atau keluarga dalam menerima kondisinya, motivasi yang dibutuhkan klien ataupun keluarga dalam 
menghadapi kondisi sakit yang diterima klien pada saat tersebut (Watson 2007; 2008; 2009; 2010; Chase, 2005; Okoye, 2012)

Rasa kepercayaan antara perawat, klien, dan keluarga tidak lepas dari bagaimana seni seorang perawat untuk melakukan pendekatan yang terapeutik terhadap klien, dengan seni pendekatan yang baik, maka akan muncul suatu rasa percaya seorang klien ketika dibantu oleh klien

Fenomena berikutnya yang banyak ditemui oleh perawat IGD saat bertugas, dimana keluarga atau pasien menggunakan benda-benda yang dianggap memiliki kekuatan menyembuhkan atau meminumkan minuman yang dianggap memiliki kekuatan menyembuhkan menurut kepercayaan mereka (keluarga dan pasien). Beberapa kejadian diatas membuat perawat memutuskan apa yang terbaik bagi pasien kritis, disatu sisi mereka memperbolehkan, disatu sisi tidak memperbolehkan melakukan atau mengenakan atau meminumkan hal-hal yang dianggap oleh perawat semakin membahayakan keselamatan pasien, dengan komunikasi yang baik terhadap keluarga tentunya.

Tindakan perawat dalam hal ini tidak bertentangan dengan nilai carative factor kesepuluh, dimana fenomena tersebut sifatnya misterius yang sulit diterangkan secara nalar scientific (keilmuan), dimana berbagai nilai spiritual yang ada pada diri klien ataupun keluarga baik bersumber dari budaya, mitos yang diyakini oleh klien, keajaiban-keajaiban yang sulit dijelaskan secara keilmuan dan nalar manusia, dimana perawat tetap menghargai nilai-nilai tersebut. Peran perawat pada nilai tersebut adalah menghargai kepercayaan klien dengan meminum obat ramuan yang dipercaya oleh klien dapat membantu menyembuhkan penyakitnya dengan mengijinkan (Chase, 2005; Watson, 2007; 2008; Cara, 2003, Okoye, 2012).

Peran perawat menghormati keyakinan tersebut tanpa menyinggung perasaan pasien dan keluarga, namun tetap memperhatikan keselamatan pasien kritis sebagai prioritas utama perawat, dengan demikian diharapkan akan meningkatkan kepercayaan pasien dan keluarga dalam setiap tindakan kegawatdaruratan yang dilakukan perawat dan tenaga kesehatan lainnya.

Usaha-usaha penyelamatan pasien kritis dilakukan perawat tidak dengan sendirinya, tapi muncul dikarenakan adanya keinginan berbuat yang terbaik untuk pasien kritis. Keinginan berbuat yang terbaik untuk pasien kritis dipengaruhi oleh berbagai sebab, diantaranya adanya keinginan dalam diri 
perawat dalam menolong pasien, dan berbuat yang terbaik untuk pasien.

Keinginan perawat menolong pasien, menurut pengalaman perawat IGD saat merawat pasien dengan kondisi kritis dikarenakan adanya suatu perasaan tertantang akan pekerjaan sebagai perawat IGD, perasaan cinta terhadap profesi keperawatan, rasa empati, perasaan kasihan dan trenyuh saat melihat pasien dengan kondisi kritis.

Perasaan tersebut sesuai dengan Carative factor Watson yang pertama, merupakan dasar pertama dan terpentingn dalam caring (secara etik dan ilmu pengetahuan (science), dimana mengenal adanya nilai-nilai humanistic (rasa kemanusiaan) dan altruistic (mementingkan kepentingan orang lain) (Watson 2007; 2008; 2009; 2010; Chase, 2005), dalam nilai kemanusiaan yang ditunjukkan oleh perawat adanya nilai kebaikan, empati, peduli dan cinta pada diri dan orang lain (klien). Rasa ingin mengutamakan kepentingan orang lain terus meningkat seiring dengan adanya suatu tekat (comitmen) dalam diri dengan adanya kebahagiaan atau rasa puas dengan memberi (menolong orang lain).

Lingkungan yang mendukung di IGD dengan adanya berbagai pelatihan kegawatdaruratan berpengaruh dan memotivasi perawat dalam bekerja sehingga muncul keinginan untuk segera berbuat dan rasa senang.

Rasa senang yang muncul dalam diri partisipan dimulai dari diri perawat sendiri yang mencintai berbagai aktivitas yang penuh dengan tantangan, suka akan kegiatan yang mampu meningkatkan adrenalin, dan adanya suatu kepuasan serta kebahagiaan tersendiri dimana mampu memberikan berbagai bentuk kebaikan bagi orang-orang yang membutuhkan bantuannya. Rasa empati yang dirasakan perawat IGD saat melakukan proses resusitasi memiliki makna yang besar dalam keperawatan pasien dengan kondisi kritis, dimana kepekaan terhadap diri dan orang lain, dimana seorang perawat mampu merasakan apa yang dirasakan terhadap dirinya, dan mengenal dan menghargai perasaan yang dirasakan oleh orang lain dan membantu perawat menjalin hubungan terapeutik secara emosional dengan klien.

Ketiga tema yang ditemukan memiliki keterkaitan satu dengan yang lain dimana keinginan berbuat yang terbaik bagi pasien kritis, dapat mempengaruhi kualitas perilaku perawat IGD dalam melakukan penyelamatan pasien kritis, dan meningkatkan kepercayaan pasien dan keluarga.

Perawat dalam memberikan usaha penyelamatan pasien dengan kondisi kritis 
didorong oleh adanya suatu keinginan berbuat yang terbaik, sehingga hal tersebut mempengaruhi kualitas pelayanan tindakan penyelamatan klien. Usaha perawat dalam melakukan tindakan penyelamatan membutuhkan kepercayaan pasien dan keluarga, dan pasien berikut keluarga membutuhkan bantuan penyelamatan akan kondisi pasien yang kritis. Rasa percaya pasien dan keluarga yang baik terhadap perawat dan keberhasilan akan penyelamatan pasien kritis membuat kepuasan tersendiri bagi perawat, sehingga rasa puas tersebut menjadi penggerak perawat dalam usaha memberikan pelayanan keperawatan yang lebih baik.

\section{KESIMPULAN}

Pengalaman caring perawat dalam menangani pasien dengan kondisi kritis, berdasarkan hasil wawancara seputar nilai-nilai caring yang muncul dari pengalaman partisipan saat merawat klien dengan kondisi yang kritis di IGD RSSA Malang. Beberapa tema yang dihasilkan berdasarkan hasil analisis transkrip wawancara, yaitu : melakukan penyelamatan pasien kritis, meningkatkan kepercayaan pasien dan keluarga, keinginan berbuat yang terbaik untuk pasien kritis.

Ketiga tema yang ditemukan memiliki keterkaitan satu dengan yang lain dimana keinginan berbuat yang terbaik bagi pasien kritis, dapat mempengaruhi kualitas perilaku perawat IGD dalam melakukan penyelamatan pasien kritis, dan meningkatkan kepercayaan pasien dan keluarga.

\section{SARAN}

Hasil penelitian ini dapat dijadikan acuan untuk membuat sebuah penelitian kualitatif khususnya yang bertemakan caring seorang perawat yang terjadi di instalasi gawat darurat, sehingga semakin membuka wacana dan menambah pengetahuan perawat maupun pendidikan khususnya dalam dunia keperawatan tentang dunia keperawatan kegawatdaruratan, ketika menghadapi klien dengan kondisi kritis.

Hasil yang telah ditemukan perlu dipertajam lagi dalam penentuan tema penelitiannya, seperti budaya yang mempengaruhi perilaku perawat maupun pasien saat dirawat di IGD atau eksplorasi caring dari sudut pandang keluarga dan pasien saat dirawat di IGD, sehingga perlu adanya observasi lebih lanjut ke area kegawatdaruratan secara langsung.

Hasil penelitian ini menunjukkan pentingnya suatu pelatihan berkesinambungan tentang pelatihan kegawatdaruratan berdampak pada kualitas pelayanan caring perawat selama bertugas, sehingga upaya yang sudah 
dibangun oleh keperawatan IGD RSSA Malang dapat dilanjutkan dan ditingkatkan lagi frekueansinya.

\section{DAFTAR PUSTAKA}

1. Bailey, D. N. 2011. Framing client care using Halldorsdottir's theory of caring and uncaring behaviors within nursing and healthcare. International Journal for Human Caring. 15: 54-66.

2. Buckner, E., Leach-Fuller, C. 2001. Honor and the creative arts in nursing: music theraphy to decrease anxiety in critical care patients. Journal of the National Collegiate Honors Council. P: 79-84.

3. Cara, C. 2003. A pragmatic view of Jean Watson's caring theory. International Journal for Human Caring.7: 51-61.

4. Chase, M. M. 2005. Emergency department nurses' lived experience with compassion fatigue. The Florida State University School of Nursing.

5. Donalek, J. G. 2004. Demystifying nursing research: phenomenology as a qualitative research method. Urologic Nursing. 24: 516-517.

6. Green, B. 2012. Feminist ethics of care to nursing practice. $J$ Nurs Care. 1: $1-4$.

7. Halligan, P. 2006. Caring for patients of Islamic denomination: critical care nurses' experiences in Saudi Arabia.
Journal of Clinical Nursing. 15: 1565-1573.

8. Holzemer. 2010. Improving health through nursing research. USA: Wiley-Blackwell.

9. Kasiram, M. 2010. Metodologi penelitian kualitatif-kuantitatif. Yogyakarta: SUKSES offset.

10. Lachman, V. D. 2012. Applying the ethics of care to your nursing practice. Medsurg Nursing. 21: 112116.

11. Laverty, S. M. 2003. Hermeneutic phenomenology and phenomenology: a comparison of historical and methodological considerations. International Journal of Qualitative Methods. 3: 1-29.

12. Laverty, S. M. 2003. Hermeneutic phenomenology and phenomenology: a comparison of historical and methodological consederations., International Journal of Qualitative Methods. 2(3). Article 3. Retrieved from:

http://www.ualberta.ca/ iiqm/backiss ues/2_3final/pdf/laverty.pdf

13. Loiselle, C. G., Profetto-McGrath, J., Polit, D. F., dan Beck, C. T. 2011. Canadian essentials of nursing research 3th edition. Canada: Lippincott \& Wilkins. 
14. Moleong, L. J. 2004. Metode penelitian kualitatif. Bandung: Remaja Rosda Karya.

15. Nazir, M. 2003. Metode penelitian. Jakarta: PT. Ghalia Indonesia.

16. Okoye, N. 2012. Jean Watson's of human caring: an analysis of nurses caring about themselves in addition to their patient. University of Virginia.

17. Rachmawati, I. N. 2013. Pengumpulan data dalam penelitian kualitatif: wawancara. Diakses pada bulan Februari 2013, melalui: http://staff.ui.ac.id/internal/13214745 4/publikasi/PENGUMPULANDATA DALAMPENELITIANKUALITATI F.pdf.

18. Ranheim, A. 2011. Expanding caring $\therefore$ theory and practice intertwined in municipal elderly care. Linkoping University: Faculty of Health Science Department of Social and Welfare Studies.

19. Rundqvist, E., Sivonen, K., Delmar, C. 2011. Sources of caring in professional nursing- a review of current nursing literature. International Journal of Human Caring. 15: 36-43.

20. Sugiyono. 2011. Metode penelitian kuantitatif, kualitatif, dan $\mathrm{R}$ \& D. Bandung: Penerbit Alfabeta.
21. Tarida, Istikarini, Barokah, et.al. 2011. Konsep caring. Universitas Indonesia : Fakultas Ilmu Kpeperawatan.

22. Tonges, M. \& Ray, J. 2011. Translating caring theory into practice "The Carolina Care Model". The Journal of Nursing Administration. 41 : 374-381.

23. Vanlaere, L., \& Gastmans, C. 2011. A personalitic approach to cara ethics. Nursing Ethics. 18: 161-173.

24. Watson, J. 2007. Watson's theory of human caring and subjective living experiences: carative factors/caritas processes as a disciplinary guide to the professional nursing practice. Texto Contexto Enferm, Florianópolis, 2007 Jan-Mar; 16(1): 129-35.

25. Watson, J. 2008. Social justice and human caring: A model of caring sciences as a hopeful paradigm for moral justice for humanity. Creative Nursing. 14(2).

26. Watson, J. 2009. Caring as the essence and science of nursing and health care. O Mundo Da Saude Sao Paulo. 33: 143-149.

27. Watson, J. 2009. Caring Science 10 Carita Processes: The implications of caring theory 